\title{
PERAN UNIVERSITAS DALAM MENINGKATKAN PARTISIPASI PEMILIH MILENIAL PADA PEMILIHAN UMUM 2019
}

\author{
Budiman N.P.D Sinaga' \\ ${ }^{1}$ Program Studi Ilmu Hukum \\ Universitas HKBP Nommensen, Medan-Sumatera Utara-Indonesia \\ e-mail: budimansinagal@uhn.ac.id
}

\begin{abstract}
In 2019 for the first time held simultaneous elections. Voter turnout in this election includes millennial. Some of the millennial are at university. Therefore, it is necessary to know the role of universities in the 2019 general election. The research was conducted with statute approach, case approach, historical approach, comparative approach, and conceptual approach. From this research, it can be found that universities have sought to increase millennial voter participation in the 2019 general election by including material on elections in courses as well as conducting public lectures.
\end{abstract}

Keywords: Millennial, Elections, Universities

\begin{abstract}
Abstrak
Pada tahun 2019 untuk pertama kali dilakasanakan pemilihan umum serentak. Pemilih pada pemilihan umum ini mencakup kaum milenial. Sebagian dari kaum milenial berada di universitas. Oleh karena itu perlu diketahui peran universitas pada pemilihan umum 2019. Penelitian dilakukan dengan pendekatan undang-undang (statute approach), pendekatan kasus (case approach), pendekatan historis (historical approach), pendekatan komparatif (comparative approach), dan pendekatan konseptual (conceptual approach). Dari penelitian ini dapat diketahaui bahwa universitas telah berusaha meningkatkan partisipasi pemilih milenial pada pemilihan umum 2019 dengan memasukkan materi mengenai pemilihan umum dalam mata kuliah serta melakukan kuliah umum.
\end{abstract}

Kata kunci: Milenial, Pemilihan Umum, Universitas

\section{A. Pendahuluan}

Pada tanggal 17 April 2019 lalu untuk pertama kali telah dilaksanakan Pemilihan Umum (Pemilihan Umum) Presiden dan Wakil Presiden, Anggota Dewan Perwakilan Rakyat (DPR), Anggota Dewan Perwakilan Daerah (DPD), Anggota Dewan Perwakilan Rakyat Daerah Provinsi (DPRD Provinsi), Anggota Dewan Perwakilan Rakyat Daerah Kabupaten (DPRD Kabupaten), serta Anggota Dewan Perwakilan Rakyat Daerah Kota (DPRD Kota) secara serentak. Sebelum ini sudah pernah dilaksanakan pemilihan serentak beberapa kali tetapi terbatas berupa Pemilihan Kepala Daerah. Pada pemilihan umum mendatang pada tahun 2024 direncanakan pemilihan umum akan meliputi seluruh pemilihan umum dan pemilihan kepala daerah. Oleh karena itu, keberhasilan pelaksanaan pemilihan umum pada tahun 2019 akan menjadi modal kuat untuk menyambut pemilihan umum serentak pada tahun 2024 .

Pergantian dari masa Orde Baru ke masa Reformasi ditunjukkan dengan perubahan berbagai peraturan perundang-undangan bahkan termasuk perubahan Undang-Undang Dasar Negara Republik Indonesia Tahun 1945 (UUD 1945). Perubahan berbagai ketentuan dalam UUD 1945 mengharuskan perubahan berbagai peraturan perundang-undangan yang sudah ada serta pembentukan berbagai peraturan perundang-undangan yang baru karena memang 
belum pernah ada. Perubahan mendasar dalam UUD 1945 mencakup juga mengenai berbagai pemilihan sehingga perlu diberlakukan Undang-Undang tentang pemilihan yang baru, antara lain Undang-Undang Nomor 22 Tahun 2014 tentang Pemilihan Gubernur, Bupati, dan Walikota, Peraturan Pemerintah Pengganti Undang-Undang Nomor 1 Tahun 2014 tentang Pemilihan Gubernur, Bupati, dan Walikota, Undang-Undang Nomor 1 Tahun 2015 tentang Penetapan Peraturan Pemerintah Pengganti Undang-Undang Nomor 1 Tahun 2014, dan Undang-Undang Nomor 7 Tahun 2017 tentang Pemilihan Umum (UU Pemilihan Umum).

Dalam Penjelasan UU Pemilihan Umum antara lain dijelaskan bahwa Pasal 1 ayat (2) Undang-Undang Dasar Negara Republik Indonesia Tahun 1945 menyatakan bahwa "Kedaulatan berada di tangan rakyat dan dilaksanakan menurut Undang-Undang Dasar". Makna dari "kedaulatan berada di tangan rakyat yaitu bahwa ralryat memiliki kedaulatan, tanggung jawab, hak dan kewajiban untuk secara demokratis memilih pemimpin yang akan membentuk pemerintahan guna mengurus dan melayani seluruh lapisan masyarakat, serta memilih wakil rakyat untuk mengawasi jalannya pemerintahan. Perwujudan kedaulatan rakyat dilaksanakan melalui Pemilihan Umum sebagai sarana bagi rakyat untuk memilih pemimpin melalui Pemilihan Presiden dan Wakil Presiden yang dipilih dalam satu pasangan secara langsung serta memilih wakilnya yang akan menjalankan fungsi melakukan pengawasan, menyalurkan aspirasi politik rakyat, membuat undang-undang sebagai landasan bagi semua pihak di Negara Kesatuan Republik Indonesia dalam menjalankan fungsi masing-masing, serta merumuskan anggaran pendapatan dan belanja untuk membiayai pelaksanaan fungsi-fungsi tersebut.

Sesuai dengan ketentuan Pasal 22E Undang-Undang Dasar Negara Republik Indonesia Tahun 1945, Pemilihan Umum untuk memilih Presiden dan Wakil Presiden, anggota DPR, anggota DPD, serta anggota DPRD diselenggarakan berlandaskan asas langsung, umum, bebas, rahasia, lima tahun sekali. Penyelenggaraan Pemilihan Umum Presiden dan Wakil jujur, dilaksanakan dengan tujuan untuk memilih Presiden dan Wakil Presiden yang memperoleh dukungan kuat dari rakyat sehingga rnampu menjalankan fungsi kekuasaan pemerintahan negara dalam rangka tercapainya tujuan nasional sebagaimana diamanatkan dalam Pembukaan dan adil setiap presiden Undang-Undang Dasar Negara Republik Indonesia Tahun 1945. Di samping itu, pengaturan terhadap Pemilihan Umum Presiden dan Wakil Presiden Undang-Undang ini juga dimaksudkan untuk menegaskan sistem presidensiil yang kuat dan efektif, di mana Presiden dan Wakil Presiden terpilih tidak hanya memperoleh legitimasi yang kuat dari rakyat, namun dalam rangka mewujudkan efektivitas pemerintahan juga diperlukan basis dukungan dari DPR.

Pemilihan Umum anggota DPR, anggota DPD, dan anggota DPRD diselenggarakan dengan menjamin prinsip keterwakilan, yang berarti setiap Warga Negara Indonesia dljamin memiliki wakil yang duduk di lembaga perwakilan yang akan menyuarakan aspirasi rakyat di setiap tingkatan pemerintahan, dari pusat hingga ke daerah, Pemilihan Umum yang terselenggara secara langsung, umum, bebas, rahasia, jujur, dan adil merupakan syarat mutlak untuk mewujudkan wakil rakyat yang berkualitas, dapat dipercaya, dan dapat menjalankan fungsi kelembagaan legislatif secara optimal. Penyelenggaraan Pemilihan Umum yang baik dan berkualitas akan meningkatlan derajat kompetisi yang sehat, partisipatif, dan keterwakilan yang makin kuat dan dapat dipertanggungjawabkan.

Secara prinsipil, Undang-Undang ini dibentuk dengan dasar menyederhanakan dan menyelaraskan serta menggabungkan pengaturan Pemilihan Umum yang termuat dalam tiga Undang-Undang, yaitu Undang-Undang Nomor 42 Tahun 2008 tentang Pemilihan Umum Presiden, Undang-Undang Nomor 15 Tahun 2011 tentang Penyelenggara Pemilihan Umum, dan Undang-Undang Nomor 8 Tahun 2012 tentang Pemilihan Umum Anggota Dewan 
Perwakilan Ralryat, Dewan Perwakilan Daerah, dan Dewan Perwakilan Rakyat Daerah. Selain itu, juga dimaksudkan untuk menjawab dinamika politik terkait pengaturan penyelenggara dan peserta Pemilihan Umum, sistem pemilihan, manajemen Pemilihan Umum, dan penegakan hukum dalam satu Undang-Undang, yaitu Undang-Undang tentang Pemilihan Umum.

Dalam Undang:Undang ini juga diatur mengenai kelembagaan yang melaksanakan Pemilihan Umum, yakni Komisi Pemilihan Umum (KPU), Badan Pengawas Pemilihan Umum (Bawaslu), serta Dewan Kehormatan Penyelenggara Pemilihan Umum (DKPP). Kedudukan ketiga lembaga tersebut diperkuat dan diperjelas tugas dan fungsinya serta disesuaikan dengan perkembangan Pemilihan Umum, kebutuhan hukum dalam Penyelenggaraan Pemilihan Umum yang lancar, sistematis, demokratis. Secara umum Undang-Undang ini mengatur mengenai penyelenggara Pemilihan Umum, pelaksanaan Pemilihan Umum, pelanggaran Pemilihan Umum dan sengketa Pemilihan Umum, serta tindak pidana Pemilihan Umum.

Perubahan politik nampak sekali berpengaruh terhadap perubahan hukum mengenai Pemilihan Umum. Menurut Moh. Mahfud MD, jika ada pertanyaan tentang hubungan kausalitas antara hukum dan politik atau pertanyaan tentang apakah hukum yang mempengaruhi politik ataukah politik yang mempengaruhi hukum maka paling tidak ada tiga macam jawaban dapat menjelaskannya. Pertama, hukum determinan atas politik dalam arti bahwa kegiatan-kegiatan politik diatur oleh dan harus tunduk pada aturan-aturan hukum. Kedua, politik determinan atas hukum karena hukum merupakan hasil atau kristalisasi dari kehendak-kehendak politik yang saling berinteraksi dan (bahkan) saling bersaingan. Ketiga, politik dan hukum sebagai subsistem kemasyarakatan berada pada posisi yang derajat determinasinya seimbang antara yang satu dengan yang lain, karena meskipun hukum merupakan produk keputusan politik tetapi begitu hukum ada maka semua kegiatan politik harus tunduk pada aturan-aturan hukum. ${ }^{1}$

Nampaknya, sekarang bangsa Indonesia sedang masuk dalam pertanyaan sebagaimana pernah disampaikan oleh Muhammad Baqir Ash-Shadr:" "Sistem mana yang baik bagi manusia dan memberikan pada mereka kehidupan sosial yang bahagia?" Jawaban untuk pertanyaan itu tentu saja harus ditemukan oleh bangsa Indonesia sendiri. Bahkan mungkin Indonesia masuk dalam pertanyaan yang disampaikan Steven Levitsky \& Daniel Ziblatt: "Apakah demokrasi kita dalam bahaya? Itu pertanyaan yang tak pernah kami bayangkan akan kami ajukan."3 Pelaksanaan pemilihan umum 2019 merupakan jawaban bangsa Indonesia atas pertanyaanpertanyaan di atas.

Menurut Jimly Asshiddiqie, ${ }^{4}$ tujuan penyelenggaraan pemilihan umum itu ada 4 (empat), yaitu: untuk memungkinkan terjadinya peralihan kepemimpinan pemerintahan secara tertib dan damai; untuk memungkinkan terjadinya pergantian pejabat yang akan mewakili kepentingan rakyat di lembaga perwakilan; untuk melaksanakan prinsip kedaulatan rakyat; dan untuk melaksanakan prinsip hak-hak asasi warga negara. Tujuan-tujuan itu jugalah yang hendak dicapai melalui pemilihan umum 2019. Keberhasilan pencapaian tujuan-tujuan itu tentu sangat dipengaruhi oleh partisipasi pemilih termasuk pemilih milenial.

Paling tidak ada dua alasan mengapa gagasan pemilihan langsung dianggap perlu. Pertama, untuk lebih membuka pintu bagi tampilnya Kepala Daerah yang sesuai dengan

\footnotetext{
${ }^{1}$ Moh. Mahfud MD, Politik hukum di Indonesia, Pustaka LP3ES Indonesia, Jakarta, 1998, hal. 9.

${ }^{2}$ Muhammad Baqir Ash-Shadr, Falsafatuna, Pandangan terhadap Pelbagai Aliran Filsafat Dunia, Mizan Pustaka, Bandung, 2014, hal. 27.

${ }^{3}$ Steven Levitsky \& Daniel Ziblatt, Bagaimana Demokrasi Mati, Apa yang Diungkapkan Sejarah tentang Masa Depan Kita, Gramedia, Jakarta, 2019, hal. vii.

${ }^{4}$ Jimly Asshiddiqie, Pengantar Ilmu Pendidikan Pancasila dan Kewarganegaraan Jilid II, Sekretariat Jenderal dan Kepaniteraan Mahkamah Konstitusi Republik Indonesia, Jakarta, 2006, hal. 175.
} 
kehendak mayoritas rakyat sendiri. Kedua, untuk menjaga stabilitas pemerintahan agar tidak mudah dijatuhkan di tengah jalan. ${ }^{5}$ Secara umum dikatakan bahwa Pemilihan Umum secara langsung itu lebih demokratis tetapi bukan berarti tanpa masalah sama sekali. Beberapa masalah yang masih muncul dan belum dapat diselesaikan misalnya menyangkut politik uang. Dalam pemilihan langsung kemungkinan penggunaan politik uang menjadi semakin terbuka dibandingkan dengan pemilihan tidak langsung seperti pemilihan oleh anggota Dewan Perwakilan Rakyat Daerah (DPRD). Permasalahan seputar Pemilihan Umum dapat dikatakan cukup rumit sehingga sampai sekarang belum kunjung selesai bahkan sekedar berkurang sekalipun. Mengingat kerumitan permasalahan tersebut maka kajian dari berbagai cabang ilmu sangat dibutuhkan, antara lain Ilmu Hukum, Ilmu Politik, Ilmu Administrasi, dan Ilmu Kewarganegaraan.

Pada Pemilihan Umum 2014, angka partisipasi pemilh hanya mencapai 75,11 persen. Komisi Pemilihan Umum (KPU) menargetkan angka partisipasi pemilih pada Pemilihan Umum 2019 mencapai 77,5 persen. Upaya meningkatkan partisipasi pemilih ini tidak akan berhasil jika hanya dilakukan oleh KPU sendiri melainkan harus dilakukan secara bersamasama termasuk oleh Perguruan Tinggi terutama universitas. Jumlah pemilih dalam Pemilihan Umum 2019 adalah 192.828.520 orang dengan pembagian berdasarkan usia sebagai berikut:

- Usia 20 tahun

: 17.501.278 orang

- Usia 21-30 tahun

: 42.843 .792 orang.

- Usia 31-40 tahun

: 43.407 .156 orang

- Usia 41-50 tahun

: $37.525 \cdot 537$ orang

- Usia 51-6o tahun

: 26.890.997 orang

- Usia 6o tahun ke atas : 22.601 .569 orang.

Dalam pembahasan di berbagai kesempatan sering kali Pemilihan Umum 2019 dikaitkan dengan generasi milenial (gen-Y). Siapakah generasi milineal itu? Berikut ini beberapa pendapat untuk kelahiran generasi milenial (gen-Y):

1. Howe dan Strauss: Individu yang lahir antara tahun $1982-2004$.

2. Iconoclast: Generasi milenial pertama lahir pada 1978.

3. Majalah Newsweek: lahir antara 1977 - 1994.

4. New York Times: mematok generasi milenial pada 1976 -1990 dan 1978 - 1998.

5. Majalah Time: kelahiran antara $1980-2000$.

Dengan demikian dapat dikatakan bahwa generasi milenial adalah generasi yang lahir antara tahun 1976 sampai 2004. Ironi tentang generasi milenial, cover Majalah Time edisi Mei 2015 berjudul "The me me me generation, millenial are lazy, entitled narrcissists, who still live with their parents." Peradaban ini adalah milik generasi berkarakter narsistik, apatis, dan cenderung individualistis. ${ }^{6}$ Pernyataan yang dikemukakan sekitar lima tahun yang lalu itu masih perlu diperhatikan pada pada tahun-tahun mendatang sebagai langkah antisipasi.

Pada saat ini, generasi milenial adalah generasi muda yang berusia antara 15-43 tahun. Usia 15-43 merupakan usia sebagian besar mahasiswa dan sebagian dosen perguruan tinggi. Dengan kata lain Pemilih milenial sebagian besar sedang berada di Perguruan Tinggi. Berdasarkan kenyataan ini, saya tertarik untuk melakukan penelitian mengenai Pemilihan Umum, perguruan tinggi, dan pemilih milenial dengan judul: Peran perguruan tinggi dalam meningkatkan partisipasi pemilih milenial pada pemilihan umum 2019.

\footnotetext{
${ }^{5}$ Ni'matul Huda, Otonomi Daerah. Filosofi. Sejarah Perkembangannya, dan Problematika, Pustaka Pelajar, Yogyakarta, 2005, hal. 204.

${ }^{6}$ Peter Mahmud Marzuki, Penelitian Hukum, Prenada Media, Jakarta, 2005, hal. 57.

${ }^{6}$ Standy Christianto, "Generasi Milenial dan Perubahan", dalam Bhaktinendra Prawiro, 7o TAHUN INDONESIA MERDEKA. Di Antara Kenyataamm dam Harapan, Pustaka Sinar Harapan, Jakarta, 2015, hal. 361.
} 


\section{B. Metode Penelitian}

\section{Metode Pendekatan}

Pendekatan-pendekatan yang digunakan dalam penelitian hukum adalah pendekatan undang-undang (statute approach), pendekatan kasus (case approach), pendekatan historis (historical approach), pendekatan komparatif (comparative approach), dan pendekatan konseptual (conceptual approach). ${ }^{7}$ Dalam penelitian ini seluruh pendekatan tersebut akan digunakan sesuai dengan permasalahan yang diteliti. Dengan demikian terbuka kemungkinan untuk menggunakan seluruh atau sebagian pendekatan tersebut sesuai dengan kebutuhan.

\section{Teknik Pengumpulan Data}

Data untuk penelitian ini akan dikumpulkan melalui penelitian kepustakaan (library reasearch) dan dilengkapi dengan penelitian lapangan berupa observasi dan wawancara. Bahan kepustakaan akan meliputi bahan hukum primer berupa Undang-Undang Dasar Negara Republik Indonesia Tahun 1945 dan berbagai Undang-Undang yang berkaitan dengan Pemilihan Umum di Indonesia. Bahan hukum sekunder berupa bahan yang memberikan kejelasan terhadap bahan hukum primer berupa hasil penelitian, makalah, artikel, surat kabar, dan lain-lain. Sedangkan bahan hukum tersier, yaitu sumber yang memberikan petunjuk dan penjelasan terhadap bahan hukum sekunder seperti kamus dan ensiklopedia. Untuk melengkapi bahan kepustakaan jika diperlukan akan dilakukan wawancara dengan pakar, pelaksana Pemilihan Umum, dan peserta pemilihan umum.

\section{Analisis Data}

Data yang akan dikumpulkan melalui penelitian ini merupakan data kualitatif sehingga analisis yang tepat untuk penelitian ini adalah analisis yuridis kualitatif. Meskipun demikian, tetap dibuka kemungkinan untuk menggunakan analisis kuantitatif mana kala data yang berhasil dikumpulkan ternyata berupa data kuantitatif juga.

\section{Pembahasan}

\section{Upaya Meningkatan Partisipasi Pemilih Dalam Pemilihan Umum 2019}

Pada umumnya pemilih pemula belum memiliki literasi politik yang memadai dan cenderung mengikuti tren di lingkungan tempat tinggalnya. ${ }^{8}$ Kenyataan ini tidak akan menjadi masalah jika lingkungan tempat tinggal para pemilih pemula dapat dikatakan baik. Akan tetapi jika sebaliknya maka perlu upaya-upaya untuk mencegah para pemilih pemula melakukan kesalahan ketika menentukan pilihan dalam pemilihan umum. Upaya pencegahan tersebut tidak akan berhasil jika hanya diserahkan kepada peserta pemilihan umum terlebih jika diserahkan kepada pelaksana pemilihan umum karena jumlah mereka sangat terbatas dibadingkan jumlah pemilih milenial. Oleh karena itu, perlu kerja sama dari semua pemangku kepentingan untuk bersama-sama melakukan berbagai upaya untuk membuat para pemilih milenial mempunyai pengetahuan yang cukup sebagai modal untuk menentukan pilihan secara benar pada pemilihan umum 2019.

Dimana-mana perguruan tinggi selalu berada atau berlokasi di tengah-tengah masyarakat atau di tengah-tengah pemukiman. Dengan kata lain, kawasan perguruan tinggi dapat menjadi lingkungan tempat tinggal bagi sebagian pemilih pemula yang kebetulan

\footnotetext{
7 Peter Mahmud Marzuki, Penelitian Hukum, hal.93.

${ }^{8}$ Karyaningtyas, S. (2019, Juni), URGENSI SOSIALISASI PEMILIHAN UMUM BAGI PEMILIH PEMULA. Majalah Ilmiah “PELITA ILMU” Vol. 2 No.1 Juni 2019, Volume 2(Issue 1), 57.
} 
bertempat tinggal di sekitar perguruan tinggi terutama universitas, termasuk tetapi tidak terbatas para pemilih pemula yang menjadi mahasiswa dari perguruan tinggi tersebut. Meskipun para pemilih pemula yang tinggal di sekitar perguruan tinggi belum tentu merupakan mahasiswa perguruan tinggi itu melainkan mahasiswa dari perguruan tinggi lain tetapi sedikit banyak tentu ada kaitan. Tentu saja suatu perguruan tinggi paling bertanggung jawab terhadap mahasiswa masing-masing tetapi tidak salah sama sekali jika memperhatikan mahasiswa dari perguruan tinggi lain.

Pada masa kampanye Pemilihan Umum 2019, para kandidat anggota legislatif ataupun para elit politik yang berkompetisi memperebutkan kursi nomor 1 dan 2 (presiden dan wakil presiden) di negeri ini semakin leluasa mengampanyekan dirinya atau memasang iklan lewat media televisi atau bahkan lewat media social. Pada masa kampanye Pemilihan Umum 2019 inilah, media benar-benar telah menjadi pasar bebas bagi para elite politik untuk beriklan secara lebih luasa. ${ }^{9}$ Penonton telivisi tentu saja cukup banyak dari kalangan pemilih pemula. Terlebih pengguna media sosial sebagian bahkan sebagian besar adalah dari kalangan pemilih pemula itu. Jika isi iklan kampanye yang dipasang di media televisi dan media sosial itu baik tentu saja sangat bermanfaat bagi pra pemilih pemula. Akan tetapi, sebaliknya jika isi iklan kampanye itu tidak bermutu maka akan memberikan pengaruh yang tidak baik kepada para pemilih pemula. Akibatnya, mereka tidak mempunyai pedoman yang baik untuk mengikuti pemilihan umum terlebih dalam menentukan pilihan yang benar sehingga banyak calon yang terpilih ketika menduduki jabatan tidak dapat melaksanakan tugas dan wenang dengan benar.

Kampanye merupakan kesempatan bagi media masa untuk meraih uang sebanyak mungkin melalui iklan. Seharusnya, hal ini tidak berarti media masa dapat begitu saja mengabaikan materi kampanye sehingga perlu menyeleksi atau menyesuaikan supaya tidak bertentangan dengan peraturan perundang-undangan yang ada maupun kode etik. Lebih jauh dari itu jika media masa tidak peduli dengan materi iklan maka tidak tertutup kemungkinan materi iklan yang diiklankan bukan memperlancar pemilihan umum melainkan sebaliknya. Pihak yang paling dirugikan dengan kenyataan seperti itu adalah para pemilih pemula karena merekalah yang terutama menjadi target iklan.

Kenyataan yang terjadi di Indonesia dan di negara lain juga adalah banyak dari pengurus partai bahkan pendiri partai merupakan pemilik dari media massa. Di Indonesia ada beberapa pimpinan partai yang mempunyai media massa, antara lain Surya Paloh sebagai pendiri dan Ketua Umum Partai Nasional Demokrat (Nasdem) merupakan pemilik dari stasiun televisi Metro TV, harian nasional Media Indonesia, dan banyak harian di berbagai daerah. Kemudian Harry Tanoesodibyo sebagai pendiri dan Ketua Umum Partai Persatuan Indonesia (Perindo) merupakan pemilik dari grup MNC yang terdiri dari beberapa stasiun televisi, banyak radio, serta beberapa koran dan majalah. Sebut saja RCTI, MNC TV, Global TV, I-News MNC Vision, MNC Play merupakan jaringan televisi dalam grup ini. Grup ini pun memiliki berbagai media cetak seperti Koran SINDO, serta jaringan radio di berbagai kota. Selanjutnya, Abdurizal Bakrie yang pernah menjadi Ketua Umum Partai Golongan Karya (Golkar) merupakan pemilik dari stasiun televisi TVONE dan ANTV. Begitu juga Chairul Tanjung sebagai pemiliha stasiun televisi Trans TV dan Trans 7 tidak dapat dilepaskan dari keterkaitan dengan Partai Politik.

Tentu saja para pimpinan media massa dapat berkata bahwa mereka tetap netral meskipun pemiliknya merupakan pendiri atau pimpinan partai. Terlebih jika disampaikan alasan bahwa ada peraturan yang membatasi jumlah iklan maksimun dari satu calon pemilihan umum di setiap media massa. Akan tetapi, selalu saja ada cara untuk menyiasati peraturan

\footnotetext{
${ }^{9}$ Lekik, O. K. (2019, Juli), ANALISIS SEMIOTIKA TERHADAP KONSTRUKSI IKLAN TELEVISI. Jurnal MetaKom, Vol. 3 (No. 1), 18.
} 
sehingga kepentingan pemilik dari media massa yang kebetulan mengikuti pemilihan umum akan selalu mendapatkan porsi yang lebih banyak daripada peserta pemilihan umum lain. Mereka tidak selalu harus tampil secara langsung melalui iklan melainkan dapat menggunakan cara-cara selain iklan juga seperti dalam pemberitaan atau dialog interaktif meskipun tidak ada jaminan mereka akan terpilih setelah tampil dominan di media massa. Beberapa pemilik media massa mengikuti pemilihan umum 2019 seperti Prananda Surya Palon yang mengikuti pemilihan Anggota Dewan Perwakilan Rakyat (DPR) dari daerah pemilihan Sumatera Utara satu.

Tentu saja keterlibatan pemilik media massa dalam pemilihan umum tidak menutup kemungkinan mempunyai sisi yang baik juga. Media massa tentu akan lebih aktif memuat pemberitaan tentang pemilihan umum. Secara langsung maupun tidak langsung pemberitaan mengenai pemilihan umum dan iklan dari para peserta pemilihan umum dapat dikatakan sebagai upaya untuk meningkatkan partisipasi pemilih. Tanpa partisipasi dari para pemilih tidak mungkin peserta pemilihan umum akan terpilih. Itulah alasan peserta pemilihan umum berusaha masuk dalam pemberitaan bahkan beriklan melalui berbagai media massa. Ajakan pertama dari peserta pemilihan umum adalah agar para pemilih berpartisipasi dalam pemilihan umum. Baru kemudian diajak untuk memilih calon peserta pemilihan umum yang beriklan itu.

\section{Peran Perguruan Tinggi Dalam Meningkatkan Partisipasi Pemilih Milenial Pada Pemilihan Umum 2019}

Komisioner Komisi Pemilihan Umum (KPU) Viryan Azis menyatakan bahwa partisipasi Pemilih pada Pemilihan Umum 2019 sebanyak 81\%, meningkat dari Pemilihan Umum Pilpres 2014 sebanyak 70\% dan Pileg 2014 sebanyak 75\%. ${ }^{10}$ Padahal sebelum pelaksanaan Pemilihan Umum 2019 dibayang-bayangi akan rendah partisipasi masyarakat, antara lain disebabkan ada ada gerakan yang mengajak untuk tidak memilih atau "Golput", seperti Komunitas 'Saya Milenial Golput' (SGM) serta 'Koalisi Masyarakat Sipil'. Padahal partisipasi Pemilih Milenial pada Pemilihan Umum 2019 sangat diharapkan mengingat jumlah pemilih milenial sangat besar. Dari keseluruhan pemilih sebanyak 192.828.520 ternyata pemilih Milenial: 42 juta dan bukan Pemilih Milenial: 150.828.520. Ternyata partisipasi Pemilih $81 \%$ atau 156.191.101. Hasil ini tentu tidak lepas dari partisipasi pemilih milenial.

Dari angka-angka di atas dapat diketahui bahwa pemilih milenial berperan penting dalam mendukung pencapaian partisipasi pemilih 81\%. Dalam rangka berupaya mewujudkan partisipasi pemilihan sebanyak mungkin banyak pihak telah melalukan berbagai upaya. Para penyelenggaran Pemilihan Umum, KPU dan Bawaslu, telah melakukan berbagai upata termasuk bekerja sama dengan perguruan tinggi. KPU dan Bawaslu antara lain telah melakukan kegiatan Goes to Campus, Goes to School. Kegiatan KPU Goes to Campus telah dilaksanakan juga di kampus Universitas HKBP Nommensen Medan. Antusiasme mahasiswa untuk mengikuti kegiatan ini sangat besar tetapi keterbatasan ruangan mengharuskan pembatasan mahasiswa yang dapat hadir dalam pertemuan itu. Pertanyaan-pertanyaan yang dilontarkan mahasiswa menunjukkan betapa besar keinginan mereka untuk mengetahui lebih dalam berbagai hal mengenai Pemilihan Umum. Mahasiswa yang memiliki pengetahuan yang baik tentang Pemilihan Umum akan dapat diharapkan menentukan pilihan secara benar dalam pelaksanaan Pemilihan Umum.

Kegiatan yang dilaksanakan di kampus memang langsung kepada sasaran tetapi bukan tanpa kelemahan. Adapun kelemahan dari kegiatan di kampus antara lain ruangan yang dapat

\footnotetext{
10 https://nasional.kompas.com/read/2019/05/27/16415251/kpu-sebut-partisipasi-pemilih-pada-Pemilihan Umum2019-capai-81-persen
} 
menampung seluruh mahasiswa dapat dikatakan tidak ada sehingga pasti tidak akan memadai kalau hanya dilaksanakan satu kegiatan saja. Selain itu, mahasiswa terikat dengan jadwal kuliah sehingga mahasiswa yang bentrok dengan jadwal kegiatan seperti Goes to Campus akan kesulitan mengikutinya walaupun tetapi terbuka kemungkinan. Mahasiswa memang tidak harus mengikuti seluruh jadwal perkuliahan karena syarat untuk mengikuti ujian hanya $80 \%$ atau $70 \%$ saja. Sayang sekali, masih saja ada dosen yang tetap menghendaki kehadiran mahasiswa 100\%. Jika kebetulan mendapatkan dosen yang semacam ini maka setiap ketidakhadiran berarti pengurangan nilai. Mahasiswa yang pernah tidak mengikuti perkuliahan otomati tidak akan mendapatkan nilai tertinggi.

Kegiatan Goes to School sangat bermanfaat bagi siswa di berbagai Sekolah Menengah Atas untuk mengetahui lebih banyak mengenai Pemilihan Umum. Pengetahuan ini dapat digunakan untuk menentukan pilihan secara tepat pada Pemilihan Umum. Perguruan tinggi tidak dapat dilepaskan dari Pemilihan Umum. Seluruh civitas akademika merupakan pemilih dalam Pemilihan Umum. Selain itu, sebagai dari civias akademika itu terlibat langsung sebagai penyelenggara Pemilihan Umum, baik di KPU, Bawaslu, maupun DKPP. Dari penelitian ini dapat diketahui beberapa langkah yang telah dilakukan Perguruan Tinggi dalam rangkat itu mensukseskan Pemilihan Umum, antara lain dengan memasukkan materi tentang Pemilihan Umum dalam berbagai mata kuliah, meliburkan kampus menjelang sampai sesudah Pemilihan Umum 2019, melakukan sosialisasi mengenai Pemilihan Umum di kampus, baik dilakukan sendiri maupun bekerja sama dengan lembaga lain.

Pada masa datang perlu dipikirkan tentang kemungkinan ada mata kuliah khusus mengenai pemilihan umum atau mata kuliah pemilihan umum. Materi yang dapat dimasukkan dalam mata kuliah pemilihan umum cukup banyak tersedia. Materi kuliah itu bisa berasal dari berbagai mata kuliah yang selama ini sudah memuat materi tentang pemilihan umum atau bisa juga berisi materi muatan yang sama sekali baru sehingga tidak akan mengganggu materi mata kuliah yang sudah berlangsung selama ini. Mata kuliah Pemilihan Umum ini bisa dimulai dengan mencoba sebagai mata kulihan pilihan. Apabila setelah berlangsung beberapa semester ternyata peminatnya banyak maka dapat diubah atau ditingkatkan menjadi mata kuliah wajib.

Di Universitas HKBP Nommensen Medan sosialisasi mengenai Pemilihan Umum dilakukan juga melalui kerja sama dengan lembaga lagi. Beberapa Pimpinan Partai Politik telah hadir di kampus untuk memberikan kuliah umum. Melalui kuliah umum ini pengetahuan mahasiswa mengenai Pemilihan Umum diperkaya dengan pengalaman para politikus terlebih pimpinan Partai Politik. Ada pun Pimpinan Partai Politik yang hadir di kampus Universitas HKBP Nommensen Medan adalah Ketua Partai Persatuan Indonesia (Partai Perindo) Hary Tanoesoedibjo dan Ketua Umum Partai Golongan Karya (Partai Golkar) Airlangga Hartarto. Demikian pula di kampus Universitas HKBP Nommensen di Kota Pematangsiantar dilakukan berbagai kegiatan kepada mahasiswa untuk meningkatkan partisipasi mereka dalam Pemilihan Umum 2019.

Kehadiran pimpinan Partai Politik di dalam kampus selalu menimbulkan polemik. Kalangan yang menolak dan menerima kehadiran pimpinan Partai Politik di kampus dapat dikatakan berimbang. Kalangan yang menolak tentu mempunyai alasan-alasan yang masuk akal seperti kemungkinan terjadi perpecahan di antara sivitas akademika karena perbedaan pandangan politik atau keanggotaan Partai Politik. Sebaliknya, kalangan yang menerima mempunyai berbagai alasan juga, antara lain kehadiran pimpinan Partai Politik itu merupakan kesempatan bagi sivitas akademika terutama mahasiswa untuk menimba ilmu dan pengalaman secara langsung dari para politikus. Ilmu dan pengalaman dari para politikus ini sangat perlu untuk melengkapi teori-teori yang telah atau akan diterima dari dosen. Bagi para 
dosen kesempatan ini merupakan kesempatan untuk menambah ilmu dan pengalaman sehingga dapat terus mengikuti perkembangan.

Dari penelitian ini ditemukan kenyataan bahwa kehadiran pimpinan suatu Partai Politik ke kampus memang meningkatkan perhatian mahasiswa terhadap pemilihan umum. Patut disayangkan ada Partai yang secara berlebihan memanfaatkan kehadiran pimpinan Partainya ke kampus. Ketika ada pimpinan Partai datang ke kampus Universitas HKBP Nommensen di Medan di sekitar kampus dipasan bendera partai dari pimpinan partai yang akan memberikan kuliah umum. Hal ini ditentang mahasiswa sehingga mereka mencopot bendera partai yang dipasang di sekitar kampus terutama yang dipasang di sekeliling kampus. Syukur mahasiwa melakukan pencopotan bendera partai itu dengan tertib sehingga tidak menimbulkan keadaan yang dapat membatalkan kehadiran dari pimpinan Partai Politik tersebut di kampus.

Pada masa datang perlu dijadwalkan secara rutin kehadiran para pimpinan Partai Politik atau paling tidak para politikus ke kampus. Kehadiran mereka dapat dikemas dalam kuliah umum yang memang sudah terjadwal. Kehadiran mereka tidak lagi hanya menjelang pemilihan umum sehingga sulit disangkal ada muatan kampanye dalam kuliah umum itu. Pengisi kuliah umumpun dibuka kesempatan luas kepada politikus dari semua Partai Politik. Melalui keterbukaan semacam ini mahasiswa dan dosen akan mendapatkan ilmu dan pengalaman yang semakin beragam dari para politikus itu. Untuk menjamin keberlangsungan kegiatan kuliah umum maka universitas dapat secara resmi menjalin kerja sama dengan Partai-Partai Politik.

Sejak dulu sudah banyak civitas akademika perguruan tinggi terutama dosen yang memasuki Partai Politik, baik sekedar sebagai anggota Partai Politik maupun pengurus Partai Politik. Dalam rangka pemilihan umum 2019 sebagian dari mereka menjadi calon anggota Dewan Perwakilan Rakyat (DPR) dan Dewan Perwakilan Rakyat Daerah (DPRD). Para dosen itu diketahui memanfaatkan status dosen ini juga untuk keberhasilannya dalam pemilihan umum. Mahasiswa yang kebetulam berdomisili di daerah pemilihan dosen merupakan sasaran empuk bagi para dosen. Hal ini dapat menjadi sesuatu yang baik ketika dipandang sebagai upaya untuk meningkatkan partisipasi pemilih juga. Akan tetapi akan menjadi sesuatu yang tidak baik ketika dikaitkan dengan nilai mahasiswa walaupun pada kenyataannya tidaklah mudah mengetahui pilihan seseorang pada Pemilihan Umum sekarang ini. Beberapa upaya pembuktian seperti memfoto kertas suara sudah menjadi hal terlarang sehingga akan merugikan peserta pemilihan umum sendiri ketika muncul masalah.

Universitas mempunyai kesempatan juga meningkatkan partisipasi pemilih di luar civitas akademika antara lain melalui kegiatan pengabdian kepada masyarakat yang dilakukan dosen dan mahasiswa. Dalam berbagai kegiatan pengabdian dapat disisipkan kegiatan yang dapat membantu masyarakat lebih memahami pemilihan umum sehingga mereka akan tergerak untuk berpartisipasi dalam pemilihan umum. Bentuk kegiatan pengabdian kepada masyarakat dosen umumnya berupa ceramah. Dalam ceramah itu dapat disampaikan secara khusus materi mengenai pemilihan umum atau secara tidak langsung dengan menyisipkannya dalam materi lain. Selain itu, para dosen akan bertemu dan bincang-bincang langsung ketika berjumpa dengan masyarakat di lokas pengabdian. Pertemuan semacam ini merupakan kesempatan yang baik sangat untuk menyampaikan hal-hal yang berkaitan dengan pemilihan umum terutama dorongan agar masyarakat berpartisipasi dengan memberikan pilihan yang banar pada saat pemberian suara.

Setelah belajar berbagai hal yang berkaitan dengan pemilihan umum di kampus maka mahasiswa juga berkesempatan untuk membagikan hal-hal yang sudah dipelajari itu kepada masyarakat. Mahasiswa mempunyai kesempatan yang istimewa berjumpa dengan pemilih milenial karena mahasiswa sendiri termasuk di dalamnya. Kegiatan seperti Kuliah Kerja Nyata 
(KKN) atau Kuliah Pengabdian Pada Masyarakat (KPPM) merupakan kesempatan baik bagi mahasiwa untuk berperan aktif meningkatkan partisipasi masyarakat pada pemilihan umum. Keberadaan mahasiswa selama beberapa minggu di tengah-tengah masyarakat merupakan kesempatan yang baik untuk menyampaikan pesan yang baik dan benar mengenai pemilihan umum.

Selain itu, mahasiswa juga dapat membagikan hal-hal yang telah dipelajari di kampus kepada keluarga. Sampai saat ini masih banyak mahasiswa yang berasal dari orang tua atau keluarga yang belum berpendidikan terlebih pendidikan tinggi. Orang tua dan keluarga tentu berharap agar para mahasiswa mempunyai ilmu dan pengetahuan yang lebih daripada mereka. Oleh karena itu, kehadiran mahasiswa untuk berbagi ilmu di tengah-tengah keluarga selalu disambut dengan baik terlebih mahasiswa yang harus pergi jauh menempuh pendidikan tinggi. Kenyataan ini merupakan peluang bagi mahasiswa untuk mempengaruhi orang tua dan keluarga agar berpartisipasi dalam pemilihan umum dengan baik dan benar.

\section{D.Kesimpulan}

Berbagai pihak, para Penyelenggara Pemilihan Umum dan perguruan tinggi terutama universitas, berusaha meningkatkan partisipasi pemilih milenial pada Pemilihan Umum 2019. KPU dan Bawaslu antara lain melakukan kegiatan Goes to school dan Goes to campus. Sementara perguruan tinggi terutama universitas memasukkan materi mengenai Pemilihan Umum dalam berbagai mata kuliah serta melakukan berbagai usaha lain seperti kuliah umum dari Pimpinan Penyelenggara Pemilihan Umum dan Partai Politik serta pengabdian kepada masyarakat. Pada masa datang perlu memasukkan materi tentang Pemilihan Umum di setiap program studi di Perguruan Tinggi terutama universitas secara permanen, bukan hanya ketika menjelang penyelenggaraan Pemilihan Umum. Materi tentang Pemilihan Umum dalam dimasukkan ke dalam mata kuliah yang ada atau memunculkan mata kuliah baru tentang Pemilihan Umum sehingga materi yang disampaikan dapat mencakup semua aspek mengenai Pemilihan Umum.

\section{Daftar Pustaka}

Agussalim Andi Gadjong, Pemerintahan Daerah, Kajian Politik dan Hukum, Ghalia Indonesia, Bogor, 2007.

Bagir Manan, Menyongsong Fajar Otonomi Daerah, Pusat Studi Hukum Fakultas Hukum Universitas Islam Indonesia, Yogyakarta, 2005. , Perkembangan UUD 1945, FH UII Press, Yogyakarta, 2004.

Jimly Asshiddiqie, Pengantar Ilmu Pendidikan Pancasila dan Kewarganegaraan Jilid I, Sekretariat Jenderal dan Kepaniteraan Mahkamah Konstitusi Republik Indonesia, Jakarta, 2006.

, Pengantar Ilmu Pendidikan Pancasila dan Kewarganegaraan Jilid II, Sekretariat Jenderal dan Kepaniteraan Mahkamah Konstitusi Republik Indonesia, Jakarta, 2006.

Karyaningtyas, S. (2019, Juni), URGENSI SOSIALISASI PEMILIHAN UMUM BAGI PEMILIH PEMULA. Majalah Ilmiah "PELITA ILMU" Vol. 2 No.1 Juni 2019, Volume Moh.Mahfud MD, Politik hukum di Indonesia, Pustaka LP3ES Indonesia, Jakarta, 1998.

Muhammad Baqir Ash-Shadr, Falsafatuna, Pandangan terhadap Pelbagai Aliran Filsafat Dunia, Mizan Pustaka, Bandung, 2014.

Lekik, O. K. (2019, Juli), ANALISIS SEMIOTIKA TERHADAP KONSTRUKSI IKLAN TELEVI. Jurnal MetaKom , Vol. 3 (No. 1), 18.

Paimin Napitupulu, Menuju Pemerintahan Perwakilan, Alumni, Bandung, 2007.

Peter Mahmud Marzuki, Penelitian Hukum, Prenada Media, Jakarta, 2017. 
Jurnal Magister Hukum Program Pascasarjana Universitas HKBP Nommensen

Volume 02 Nomor o1 Januari 2021 Halaman. 01-11 e-ISSN: 2723-164X p-ISSN: 2722-9858

http://ejournal.uhn.ac.id/index.php/opinion

Steven Levitsky \& Daniel Ziblatt, Bagaimana Demokrasi Mati, Apa yang Diungkapkan Sejarah tentang Masa Depan Kita, Gramedia, Jakarta, 2019.

Sri Soemantri, Tentang Lembaga-lembaga Negara Menurut UUD 1945, Citra Aditya Bakti, Bandung, 1989.

Ni'matul Huda, Pendidikan Pancasila dan Kewarganegaraan Indonesia, RajaGrafindo Persada, Jakarta, 2005. , Ilmu Negara, Rajawali Pers, Jakarta, 2010.

, Otonomi Daerah. Filosofi. Sejarah Perkembangannya, dan Problematika, Pustaka Pelajar, Yogyakarta, 2005.

Sadu Wasistiono \& Yonatan Wiyoso, Meningkatkan Kinerja Dewan Perwakilan Rakyat (DPRD), Folusmedia, Bandung, 2009.

Standy Christianto, "Generasi Milenial dan Perubahan", dalam Bhaktinendra Prawiro, 70 TAHUN INDONESIA MERDEKA. Di Antara Kenyataamm dam Harapan, Pustaka Sinar Harapan, Jakarta, 2015.

\section{Peraturan Perundang-undangan}

Undang-Undang Dasar Negara Republik Indonesia Tahun 1945.

Undang-Undang Nomor 22 Tahun 2014 tentang Pemilihan Gubernur, Bupati, dan Walikota.

Peraturan Pemerintah Pengganti Undang-Undang Nomor 1 Tahun 2014 tentang Pemilihan Gubernur, Bupati, dan Walikota.

Undang-Undang Nomor 1 Tahun 2015 tentang Penetapan Peraturan Pemerintah Pengganti Undang-Undang Nomor 1 Tahun 2014 tentang Pemilihan Gubernur, Bupati, dan Walikota menjadi Undang-Undang.

Undang-Undang Nomor 7 Tahun 2017 tentang Pemilihan Umum. 